Schering Company (personal communication) has information from 16 pregnancies, all normal, in which there was low dose exposure. The company is also aware of four pregnancies exposed to the Hammerstein regimen. Two normal girls were born after treatment with $50 \mathrm{mg}$ cyproterone acetate daily during the first 10 and 18 weeks of pregnancy, respectively. Two boys were born after exposure to $100 \mathrm{mg}$ cyproterone acetate daily but little is known about these pregnancies. One of them occurred in Britain (treatment for 20 weeks, child probably normal) and the other in the United States (data inadequate but possible exposure for six weeks, outcome unknown) (Schering Company, personal communication).

In our patient we considered that the male fetus was at particular risk of genital malformation because of the high dose and prolonged exposure to the antiandrogenic drug during a sensitive period of fetal life. Postabortal examination of the fetus, however, showed no sign of anatomical malformation, so the abortion may have been unnecessary. Nevertheless, normal genital anatomy does not exclude the risk of disturbed sexual function in adult life. ${ }^{4}$ The question what to advise should another patient be exposed to cyproterone acetate during early pregnancy remains open. Our case and the few available data from other patients suggest that apparently normal development may occur in a male fetus and that induced abortion may therefore not be absolutely necessary.

1 Cooke ID. Hirsutism and virilism. In: Shearman RP, ed. Clinical reproductive endocrinology. Edinburgh: Churchill Livingstone, 1985:432-51.

2 Neumann F, Steinbeck H. In: Eichler O, Farah A, Herken H, Welch AD, eds: Handbook of experimental pharmacology. NS. Vol XXXV/2. Heidelberg, New York: Springer-Verlag, 1974:351-82.

3 Hammerstein J, Meckies J, Leo-Rossberg I, Matzl L, Zielkse F. Use of cyproterone acetate (CPA) in the treatment of acne, hirsutism and virilism. F Steroid Biochem 1975;6:827-36. 4 Gómez F, Monnier B, Lemarchand-Béraud T. Foetal exposure to low doses of cyproterone acetate
in the rat leads to functional endocrine abnormalities despite normal sexual morphogenesis. Acta in the rat leads to functional endocrine

5 Statham BN, Cunliffe WJ, Clayton JK. Conception during "Diane" therapy-a successful outcome. Br f Dermatol 1985;113:374.

(Accepted 3 December 1986)

Department of Obstetrics and Gynaecology, Uppsala University, Akademiska Sjukhuset, S-751 85 Uppsala, Sweden

T BERGH, MD, assistant professor

O BAKOS, MD, research fellow

Correspondence to: Dr Bergh.

\section{Coagulation studies in cases of intrauterine death: overkill?}

In many obstetric units coagulation profiles are performed on all women with abruptions, moderate to severe pre-eclampsia, and intrauterine fetal death. While not doubting their value in the first two cases, we wondered whether the routine use of these tests in all cases of intrauterine fetal death can be justified.

\section{Patients, methods, and results}

All stillbirths at Dudley Road Hospital in 1980-5 were studied. Those associated with conditions known to cause coagulation abnormalities - that is, abruptions and pre-eclampsia-were excluded. This left a total of 91 intrauterine deaths, for 82 of whom notes were traced and any coagulation investigations noted. In 77 women we were able to estimate the maximum possible time that the fetus had been dead (table).

Twenty women had no coagulation studies performed: 12 of these delivered soon after arrival, giving no time for any investigations. The remaining 62 women had some coagulation investigations. Fifty eight had their activated partial thromboplastin time measured. The range was $23-45$ seconds (mean (SD) 34 (6.7) seconds). Fifty six had a prothrombin test. The range was $11-14$ seconds this was not appreciably different from control values. Fifty four had a platele count. The range was $130-575 \times 10^{9} / 1$ (mean $\left.280(98) \times 10^{9} / 1\right)$. Twenty one had fibrin degradation products measured. Eighteen patients had a result of $\leqslant 10 \mathrm{mg} / \mathrm{l}$, and three of $>10 \mathrm{mg} / \mathrm{l}<40 \mathrm{mg} / \mathrm{l}$. Fifteen had their fibrinogen concentrations measured. The range was $2 \cdot 5-6 \cdot 0 \mathrm{~g} / \mathrm{l}$ (mean $3 \cdot 7(1 \cdot 0) \mathrm{g} / \mathrm{l}$ ). None of these values was clinically important or differed significantly from the normal

Approximate maximum time the fetus had been dead in utero

$\begin{array}{lcccccccccc}\text { Time (days): } & 1 & 2-4 & -7 & -10 & -13 & -16 & -19 & -22 & -28 \\ \text { No of patients: } & 19 & 15 & 22 & 2 & 1 & 8 & 1 & 8 & 1\end{array}$

range. None of the 82 patients had any symptoms that could be associated with coagulation problems.

\section{Comment}

During the 1950s diagnosing fetal death with certainty was sometimes difficult. Spontaneous labour was awaited, which resulted in some fetuses remaining dead in utero for many weeks. In reviewing 14 papers from this era (over 133 cases) we found only two cases in which coagulation abnormalities occurred within five weeks after presumed fetal death, one after four weeks ${ }^{1}$ and one after 14 days. ${ }^{2} \mathrm{~A}$ case was described in an unbooked patient 10 days after "movements ceased," but the clinical history and examination suggested a much longer period of intrauterine death. ${ }^{3}$

One study reported more than 100 women who had retained a dead fetus in utero for more than one week, 50 of them for longer than five weeks (range 5-19 weeks, mean eight weeks). ${ }^{4}$ Fibrinogen concentrations started to fall after three to four weeks, but this was not clinically important before five weeks. After five weeks about $25 \%$ of women developed defective haemostatic function. Hodgkinson $e t$ al found a clinically unimportant fall in fibrinogen concentration within two weeks, which recovered only to fall again weeks later. ${ }^{5}$ This fall in fibrinogen concentration might be similar to that which occurs after normal delivery.

Thus other reports suggest that within three weeks after fetal death no abnormalities are found by coagulation studies and no clinically important abnormalities are likely before five weeks; our data support these statements. The diagnosis of intrauterine death can now be made with certainty, and prostaglandins and oxytocin can reliably and safely empty the uterus. Consequently it is rare for dead fetuses to be left in utero for any length of time, as our study confirms. An on call "clotting screen" costs about $£ 11$, but the resulting delay in starting epidural anaesthesia and further distress to the mother must be considered.

We believe that routine coagulation screening when the fetus has been known to be dead for three weeks or less is not necessary from an obstetric or anaesthetic viewpoint. A policy of performing such investigations on those women with a fetus in utero for longer than this time, or where clinical indications or doubts exist, gives a good safety margin and would be more rational.

1 Howie BO. Intrauterine foetal death with defective maternal blood clotting mechanism. Proceeding of the Royal Society of Medicine 1956;49:93-6.

2 Goldstein DP, Reid DE. Circulating fibrinolytic activity-a precursor of hypofibrinogenaemia following fetal death in-utero. Obstet Gynecol 1963;22:174-80.

3 Lemer R, Margolin M, Slate WG, Rosenfeld H. Heparin in the treatment of hypofibrinogenemi complicating fetal death in-utero. Am J Obstet Gynecol 1967;97:373-8.

4 Pritchard JA. Fetal death in-utero. Obstet Gynecol 1959;14:573-80.

5 Hodgkinson CP, Thompson RJ, Hodari AA. Dead fetus syndrome. Clin Obstet Gynecol 1964;7:349:60.

(Accepted 8 December 1986)

Department of Obstetrics and Gynaecology, Dudley Road Hospital, Birmingham B18.7QH

G CONSTANTINE, MRCP,'MRCOG, registrar

V MENON, MD, MRCOG, senior registrar

Correspondence to: Dr Constantine

\section{Primary nocturnal enuresis in children with vesicoureteric reflux}

Despite numerous reports on the prevalence of genitourinary tract abnormalities in enuretic children ${ }^{1-3}$ there is no information about the prevalence of primary nocturnal enuresis in children who have anatomic abnormalities of the urinary tract. We evaluated the prevalence of primary nocturnal enuresis in 67 children who had vesicoureteric reflux.

\section{Patients, methods, and results}

Fifty patients with unilateral and 17 with bilateral primary vesicoureteric reflux were investigated ( 41 girls, 26 boys; age range $5-14$, mean 8.1 years; 49 children were aged 9 or under). The severity of reflux was graded from I to $\mathrm{V}$ according to the international classification; 49 patients had grade I or II reflux and 18 grades III to V. Thirty four children had experienced a recent urinary infection and had been investigated for the first time by voiding cystourethrography. The remaining 33 children had a history of urinary infection between the age of 2 weeks and 3 years; they had undergone voiding cystography at least twice as part 
of their previous investigation and follow up. The control group comprised 530 normal children seen in hospital for reasons unrelated to the genitourinary tract (308 girls, 222 boys; age range 5-14, mean 8.8 years; 375 were aged 9 or under). Statistical analysis was with fourfold tables $\chi^{2}$ test.

Twenty three patients (34\%) with reflux but only $42(8 \%)$ of the controls were enuretic $\left(\chi^{2}=42.7, p<0.001\right)$ (table). There was no significant difference in the prevalence of primary nocturnal enuresis between children with different grades of reflux or between children with bilateral and unilateral reflux: $15(31 \%)$ of 49 with grade I or II vesicoureteric reflux and eight $(44 \%)$ of 18 with grades III-V were enuretic, and $15(30 \%)$ of 50 children with unilateral and eight $(47 \%)$ of 17 with bilateral vesicoureteric reflux were enuretic. The prevalence of enuresis was the same in the children with reflux aged 9 or under as in those aged 10-14 $\left(\chi^{2}=\right.$ $0 \cdot 01$ ), but the difference in the prevalence of enuresis between the same age groups in normal children was considerable $\left(\chi^{2}=3.49,0.05<p<0 \cdot 1\right)$ (table). Eight (24\%) of the 34 children who had vesicoureteric reflux and had had a recent urinary infection were enuretic compared with $42(8 \%)$ of the 530 controls $\left(\chi^{2}=\right.$ $9.62,0.001<p<0.01)$. Furthermore, none of the enuretic children who had reflux and had had a recent urinary infection stopped bed wetting after their infection had been treated. Enuresis was twice as common in children who had a longstanding infection (five of 13) as in those with a recent infection (eight of 34) $\left(\chi^{2}=3 \cdot 57,0 \cdot 05<p<0 \cdot 1\right)$.

Prevalence of primary nocturnal enuresis in children who had vesicoureteric reflux

\begin{tabular}{lcc}
\hline & $\begin{array}{c}\text { No of } \\
\text { children }\end{array}$ & $\begin{array}{c}\text { No (\%) with } \\
\text { enuresis }\end{array}$ \\
\hline $\begin{array}{l}\text { Children with reflux: } \\
\text { Aged 5-9 }\end{array}$ & 49 & $17(35)$ \\
Aged 10-14 & 18 & $6(33)$ \\
\hline Total & 67 & $23(34)$ \\
\hline Controls: & & \\
Aged 5-9. & 375 & $35(9)$ \\
Aged 10-14 & 155 & $7(5)$ \\
\hline Total & 530 & $42(8)$ \\
\hline
\end{tabular}

\section{Comment}

Our results showed a fourfold increase in the prevalence of primary nocturnal enuresis among children who had vesicoureteric reflux compared with normal children. It is difficult to establish a direct causal relation between the presence of reflux and the occurrence of enuresis; some urodynamic studies, however, have shown that detrusor instability in children who have vesicoureteric reflux is quite common, ${ }^{4}$ and bladder instability also often occurs in enuretic children. ${ }^{5}$

In enuretic children who have vesicoureteric reflux the various stressful events that are related to their urological problem do not seem to be solely responsible for the higher prevalence of enuresis among them. The prevalence of enuresis remained high even in the group of children who had had only a recent urinary infection. Furthermore, the prevalence of primary nocturnal enuresis in children who had reflux was uninfluenced by the presence of a urinary infection.

The prevalence of primary nocturnal enuresis remained virtually unchanged in children whe had reflux in the two age groups 5-9 and 10-14 years, unlike that in normal children. It would be interesting to discover whether the spontaneous resolution or surgical cure of reflux also has a therapeutic effect on enuresis.

1 Essen J, Peckham C. Nocturnal enuresis in childhood. Dev Med Child Neurol 1976;18:577-89. 2 Mahony DT. Studies of enuresis. I. Incidence of obstructive lesions and pathophysiology of enuresis. F Urol 1971;106:951-8.

3 Redman JF, Seibert JJ. The uroradiographic evaluation of the enuretic child. $\mathcal{F}$ Urol 1979;122: 799 801.

4 Taylor CM, Corkery JJ, White HR. Micturition symptoms and unstable bladder activity in girls with primary vesicoureteric reflux. Brf Urol 1982;54:494-8.

5 Booth CM, Gosling CM. Histological and urodynamic study of the bladder in enuretic children. Br f U.rol 1983;55:367-70.

(Accepted 3 December 1986)

First Department of Paediatrics, Athens University, Aghia Sophia Children's Hospital, Athens 115 27, Greece

CHRISTOS BACOPOULOS, MD, associate professor in paediatric nephrology THEMISTOKLES KARPATHIOS, $\mathrm{MD}$, associate professor in paediatrics JOHN PANAGIOTOU, MB, paediatric registrar

POLYXENI NICOLAIDOU, $M D$, lecturer in paediatrics

PHILIP ANDROULAKAKIS, MD, associate professor in paediatric urology

JOHN MESSARITAKIS, MD, associate professor in paediatrics

Correspondence to: Dr Nicolaidou.

\section{Extranodal lymphoma in a haemophiliac negative for antibody to HIV}

Diseases associated with serum antibodies to human $T$ cell lymphotropic virus type I and human immunodeficiency virus (HIV) include lymphoproliferative neoplasia. ${ }^{2}$ Among haemophiliacs treated with factor VIII concentrates the prevalence of seropositivity for antibody to HIV is high, and non-Hodgkin's lymphoma has been reported in patients with the antibody. ${ }^{3}$ We report the occurrence of extranodal non-Hodgkin's lymphoma in a haemophiliac given concentrate whose cell mediated immunity was impaired but who was negative for antibody to HIV.

\section{Case report}

A 50 year old patient deficient in factor VIII $(<0.01 \mathrm{U} / \mathrm{ml})$ was admitted with haemarthrosis of the right knee. He was taking ibuprofen $1200 \mathrm{mg}$ daily and dihydrocodeine for chronic haemophiliac arthritis. He had received 75000 units of factor VIII concentrate in the previous four years. His bleeding episode was treated with transfusion of factor VIII concentrate, analgesia, and physiotherapy. He was negative for antibody to HIV by both enzyme linked immunosorbent assay (ELISA) and Western blotting. Tests for antibodies to human T cell lymphotropic virus type I also yielded negative results. Intradermal infection of both purified protein derivative and dinitrochlorobenzene yielded no reaction. The T lymphocyte ratio was 0.36 (T helper cells $0.7 \times 10^{9} / 1$ and $\mathrm{T}$ suppressor cells $1.925 \times 10^{9} / 1$ )

Two weeks after admission he had a haematemesis and his blood pressure fell to $80 / 50 \mathrm{~mm} \mathrm{Hg}$. Three units of blood and 3000 units of factor VIII concentrate were transfused. Endoscopy showed superficial gastric ulcers; ibuprofen was stopped, and he was treated with factor concentrate and ranitidine.

Though there was no further gastric bleeding, his renal function deteriorated, having been normal on admission. Serum urea concentration on the day of the haematemesis was $32.3 \mathrm{mmol} / \mathrm{l}$ and creatinine $180 \mu \mathrm{mol} / \mathrm{l}$; a week later creatinine had risen to $370 \mu \mathrm{mol} / \mathrm{l}$. He was initially presumed to have acute tubular necrosis, and fluid overload was corrected with diuretics. Renal ultrasonography showed both kidneys to be enlarged. Management was complicated by chest infections, and on one occasion he suffered septicaemia and cardiopulmonary arrest, from which he was resuscitated. Fourteen days after his haematemesis serum creatinine concentration was $900 \mu \mathrm{mol} / /$. Renal biopsy was not performed because of the risk of bleeding: an inhibitor to factor VIII was detected six weeks after the onset of renal failure. Prednisolone $40 \mathrm{mg}$ was then started, with a transient improvement in renal function (creatinine concentration $450 \mu \mathrm{mol} / /$ ). His condition deteriorated; and he was considered unsuitable for dialysis. He died of bronchopneumonia and septicaemia due to Escherichia coli.

At necropsy both kidneys were enlarged $(250 \mathrm{~g})$ with uniform pale cut surfaces. The corticomedullary junction was poorly defined, and there was no evidence of scarring or haemorrhage. Microscopy showed a diffuse, mainly cortical infiltrate of large lymphoid cells (figure), which were pleomorphic with convoluted nuclei and numerous mitoses. Results of immunocytochemical staining with common leucocyte antigen were positive. Fresh tissue was not available to define the lymphocyte infiltrate in more detail. There was no evidence of tumour infiltrate in the rest of the organs examined.

\section{Comment}

The presentation, site, and nature of the lymphoma in our patient were rare; to our knowledge this is the first report of an extranodal non-Hodgkin's

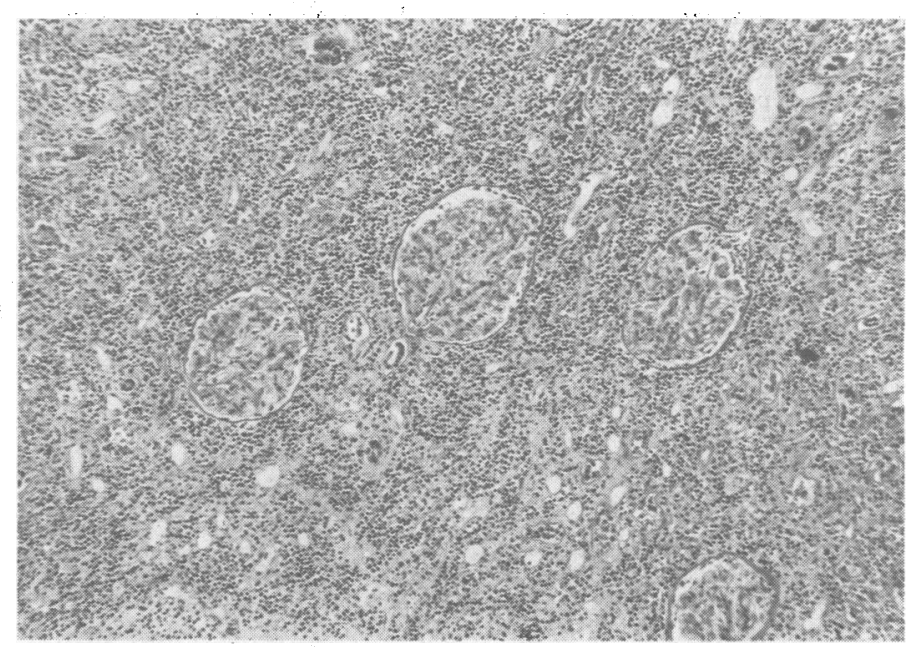

Renal cortex expanded by diffuse tumour infiltrate with relative sparing of glomeruli. Many tubules are atrophic; the rest show degenerative changes. 